\title{
From Authentic Happiness to Well-Being: The Flourishing of Positive Psychology
}

\section{Da Felicidade Autêntica ao Bem-Estar: A Psicologia Positiva em Florescimento}

\author{
Fabio Scorsolini-Comin ${ }^{*}, a$, Anne Marie Germaine Victorine Fontaine ${ }^{b}$, \\ Silvia Helena Koller ${ }^{c} \&$ Manoel Antônio dos Santos ${ }^{d}$ \\ ${ }^{a}$ Universidade Federal do Triângulo Mineiro, Uberaba, Minas Gerais, Brasil, \\ ${ }^{b}$ Universidade do Porto, Porto, Portugal, \\ ${ }^{c}$ Universidade Federal do Rio Grande do Sul, Porto Alegre, Rio Grande do Sul, Brasil \\ ${ }^{d}$ Universidade de São Paulo, Ribeirão Preto, São Paulo, Brasil
}

\begin{abstract}
The present study aims to present paradigm shifts from the authentic happiness theory (2002) to the well-being theory (2011), both developed in Positive Psychology by Martin Seligman. The well-being theory adds fulfillment and interpersonal relationships to the elements already included in the first theory (positive emotions, engagement and meaning), highlighting that well-being does not depend only on individual aspects but on issues related to context and interpersonal relationships. Whereas authentic_happiness seeks life satisfaction, well-being aspires to flourishing - a more complex and dynamic construct. Well-being theory opens the possibility of developing public policies related to promotion of quality of life without ruling out the need for constant review of such approach.

Keywords: Happiness, well-being, health promotion, Positive Psychology.
\end{abstract}

\begin{abstract}
Resumo
O objetivo do presente estudo é apresentar as mudanças paradigmáticas da teoria da felicidade autêntica (2002) para a teoria do bem-estar (2011), ambas desenvolvidas na Psicologia Positiva por Martin Seligman. A teoria do bem-estar acrescenta a realização e os relacionamentos interpessoais aos elementos já incluídos na primeira teoria (emoções positivas, engajamento, sentido), destacando que o bem-estar não dependeria apenas de aspectos individuais, mas de questões ligadas ao contexto e relacionamentos interpessoais. Enquanto a felicidade autêntica buscava a satisfação com a vida, o bem-estar almeja o florescimento, construto mais complexo e dinâmico. A teoria do bem-estar abre possibilidade de que se desenvolvam políticas públicas relacionadas à promoção da qualidade de vida, sem excluir a necessidade de constante revisão dessa abordagem.

Palavras-chave: Felicidade, bem-estar, promoção da saúde, Psicologia Positiva.
\end{abstract}

\section{The Positive Psychology Perspective}

Positive Psychology, considered one of the most recent approaches in psychology, has been prominent since the late 1990s. However, the term Positive Psychology was first referred by Maslow in 1954 in his studies regarding motivation and personality (Snyder \& Lopez, 2009). At the end of the 1990s, Martin E. P. Seligman, in the United States, legitimized the use of this term to denote a theoretical approach proposed for the understanding of the human being.

* Endereço para correspondência: Departamento de Psicologia, Universidade Federal do Triângulo Mineiro, Avenida Getúlio Guaritá, 159, $3^{\circ}$ andar, Abadia, Uberaba, MG, Brasil 38025-440. E-mail: scorsolini_usp@yahoo. com.br, fontaine@fpce.up.pt, silvia.koller@gmail.com e masantos@ffclrp.usp.br.

Apoio: CAPES, CNPq e Banco Santander.
According to Sheldon and King (2001), Positive Psychology is the scientific study of the ordinary human strengths and virtues. For Seligman (2000), Positive Psychology is the study of feelings, emotions, institutions and positive behaviors that have human happiness as their final goal. For Snyder and Lopez (2009, p. 17), “(Positive Psychology) is the scientific and applied approach to uncovering people's strengths and promoting their positive functioning". Also according to these authors, the science and practice of Positive Psychology are directed toward the identification and understanding of human qualities and virtues, as well as promoting conditions for people to have happier and more productive lives. From this perspective, the meaning of happiness is not understood as something fleeting and fluctuating but as a relatively permanent feeling experienced over time.

Historically, it can be said that the movement known as Positive Psychology was developed from the 1990s 
by Martin Seligman, then the president of the American Psychological Association (APA), along with other prominent researchers in the international arena, such as Ken Sheldon, Barbara Fredrickson, Kevin Rathunde, Mihaly Csikszentmihalyi, Robert Emmons, Carol Ryff and Jon Haidt, among others. This perspective primarily proposes modifying the focus of psychology, which shifts from attempting to repair the "worst things" in life and the emphasis on studies exclusively devoted to mental illness to building positive qualities (Delle Fave, 2006; Snyder \& Lopez, 2009). This innovative proposal arises from the observation that psychology, until then, leaned primarily on the development deficits, disorders, psychopathologies and mental illness. This effort to highlight health, as opposed to illness, began to be stressed after the Second World War with veterans who returned from battlefields and needed to be reinserted into society and assisted in their needs. By removing the focus from mental illness, the possibility to highlight the positive aspects, strengths, virtues and potential of the human being was opened, focusing on health prevention and promotion.

According to Seligman (2002), Positive Psychology is based on three main concepts, namely: the study of positive emotion; the study of positive traits or qualities, especially strengths and virtues, including such abilities as intelligence and athleticism; and finally, the study of the so-called positive institutions, such as democracy, family and freedom, which support the manifestation of virtues that, in turn, support the possibility of generating positive emotions. Positive Psychology aims to highlight the positive experiences, translated by positive emotions, happiness, hope, joy; by individual positive characteristics, character, strength, courage, virtue; and by positive institutions (Larrauri, 2006; Park \& Peterson, 2007; Peterson \& Seligman, 2003; Seligman, 2002).

Considering the scientific production on Positive Psychology in the Brazilian context, Paludo and Koller (2007) indicate that there is still only scarce information concerning this significant change occurring in psychology, with a gradual change being observed in the focus and approach of the Brazilian studies on human development. This scarcity of research may be due to the recent nature of the studies in the area because this field was officially "born" in the late 1990s and early 2000s. As Positive Psychology is a current that emerged in the United States, its impact on the Brazilian scene is still slight compared to European countries but has found fertile ground in Brazil for the production of scientific knowledge, especially starting in the year 2000 (Albuquerque \& Tróccoli, 2004; Camargo, Abadi, \& Giacomoni, 2011; Giacomoni \& Hutz, 2008; Lemos \& Cavalcante, 2009; Paludo \& Koller, 2007; Paschoal \& Tamayo, 2008; Passareli \& Silva, 2007; Prati \& Koller, 2011; Rodrigues \& Da Silva, 2010; Yunes, 2003). In recent surveys (Scorsolini-Comin \& Santos, 2009, 2010; 2011a, 2011b, 2012), it was noted that the Brazilian level of research still contrasts with the abundance of European and North-American studies (Barros, Martín, \& Pinto, 2010; Delle Fave, 2006; Larrauri, 2006; Park \& Peterson, 2007; Pérez, 2009; Peterson \& Seligman, 2003; Seligman, 2002, 2004, 2011; Snyder \& Lopez, 2009).

In Brazil, Calvetti, Muller and Nunes (2007) noted that there is still not a work group at ANPEPP (Associação Nacional de Pesquisa e Pós-graduação em Psicologia National Association for Research and Graduate Studies in Psychology) dedicated to Positive Psychology, although a meeting conducted in Florianópolis (SC) in 2006 and the publishing of the book Resiliencia e Psicologia Positiva [Resilience and Positive Psychology] (Dell'Aglio, Koller, \& Yunes, 2006) can be highlighted as important milestones of the movement in the national context. From the point of view of measuring in the Positive Psychology field, related to aspects of subjective well-being and correlated notions, such as flow, self, satisfaction and locus of control, among others, the studies point to the need for production of tools adapted and validated to the Brazilian context (Albuquerque \& Tróccoli, 2004; Paschoal \& Tamayo, 2008; Scorsolini-Comin \& Santos, 2010), preferably built from national samples, which also does not exclude the need to investigate the classical international tools, their assumptions, adaptation, transcultural validation and applicability (Ferraz, Tavares, \& Zilberman, 2007) in various situations, populations and cultural contexts.

Considered to be a recent approach, Positive Psychology is developing rapidly, especially considering that its propagation and discussion in academic circles date back slightly over a decade. In addition to the constant development of this perspective, the possibility of systematizing the already consolidated production in the field is opened to gain knowledge on the gaps and potential for new studies. It is in this direction that the theoretical foundations that underlie Positive Psychology have advanced along this short trajectory. The authentic happiness movement, formulated in 2002, is currently being questioned, thereby allowing the ascendance of the well-being movement, formulated in 2011. Both movements were developed by Seligman from several empirical studies with the participation of researchers from all over the world. The transition from a movement to another is automatic and exclusionary but must be understood as an ongoing paradigm shift. Thus, understanding this process is critical to align the Positive Psychology goals to those of a psychological science permanently committed to social change and the human well-being.

Therefore, the objective of this study is to discuss the paradigm changes from the authentic happiness movement to the well-being one under the Positive Psychology perspective. To this end, this study begins with a presentation of the leading researcher on Positive Psychology, Martin E. P. Seligman, seeking to identify how his biography reflected or allowed such changes. 
Scorsolini-Comin, F., Fontaine, A. M. G. V., Koller, S. H. \& Santos, M. A. (2013). From Authentic Happiness to Well-Being: The Flourishing of Positive Psychology.

\section{Seligman, the Researcher and his Work}

From the 1990s, Martin E. P. Seligman became a recurring name in Psychology publications and conferences worldwide. Before this period, Seligman was known for his experimental research and in the psychopathology field. After more than 20 years since his initial thoughts on Positive Psychology were presented to the scientific community, his work has been increasing each year, considering his investments not only in the dissemination of Positive Psychology in academia or outside of it but in transcultural studies that contributed to the improvement of his concepts on human development.

Seligman was born in the United States in 1946, graduated with a major in philosophy at Princeton University (1964) and obtained a Ph.D. in psychology from the University of Pennsylvania (1967), where he currently teaches in the psychology department. The main influence during his training was Experimental Psychology followed by extensive clinical practice. As a professor of psychopathology, he once asked himself about the tendency of the psychological science to focus their studies in diseases and dysfunctional aspects, ignoring the positive aspects of development. In 1997, when Seligman held the presidency of the APA, his studies began to be disseminated worldwide. The position held as the president of the largest psychology entity conferred prestige and prominence to his research.

Positive Psychology, for Seligman (2011), must maintain its commitment to the human being, not allowing itself to be confined to university walls but serving people and their questions. This questions include the search for health and well-being, as well as permanent accomplishment, as announced in his work from 2004. Seligman has published hundreds of scientific articles and has books have been translated in several countries; he is considered one of the best-known contemporary authors and one who contributed the most to the construction of psychology in the $21^{\text {st }}$ century. One of the most recent and commonly accepted ways to understand scientific productivity and the consequent individual importance of researchers is the $h$ index measurement, developed by Hirsch (2005). In the study by Buela-Casal, Olivas-Avila, Musi-Lechuga and Zych (2011), the $h$ indices of researchers that occupied the presidency of APA since 1940 are presented and discussed. In the ranking of these researchers, Seligman occupies fourth place, therefore placing among the most read and cited authors of the twentieth century. Seligman's $h$ index is 41 . It should be considered that these findings corroborate the testimonials that claim that his work is respected and valued throughout the world, despite his being the target of criticism, some of which has been received and duly answered by the author (Seligman, 2011).

It should be considered that the movement dubbed Positive Psychology emerged from Seligman's initiative along other renowned researchers who have contributed for this field to improve and gain prestige in the scientific community. Thus, we cannot highlight only the work of Seligman as the epicenter of this discussion. Carol Ryff (1989), for example, proposed a model of positive functioning based on the concept of psychological well-being, encompassing such dimensions as self-acceptance, personal growth, life purpose, environmental domain and positive relationships with others, which involve the ability to establish strong empathy, affection and intimacy.

Another prominent researcher in the field of Positive Psychology is Mihaly Csikszentmihalyi (1997), who developed studies on the flow state, which is considered one of the most pervasive concepts in the area. The concept of flow is defined as a state of optimal experience that people express when they are intensely involved in what they are doing. This state can be represented as a channel on a scheme of challenge versus skill, separating the states of boredom and anxiety: as the challenges increase, people become more anxious, and when they decrease, they get bored and find it a dull experience. Thus, the flow state may manifest when the challenge and ability are high and in balance, which has subsidized the planning of interventions in different professional and educational sectors. The presence of flow depends on the combination of internal and external conditions. In terms of external conditions, we highlight the task characteristics, which should have concrete goals such that people can adjust. Internally, there are the personal characteristics, such as self-control and ability of concentrated attention, which are strongly associated to the flow states (Mesurado, 2009).

Regarding the positivity concept, we highlight the studies by Alice Isen and Barbara Fredrickson. Isen (1987) found that people who experience moderate positive emotions tend to help others more, to be more flexible in their thoughts and to produce solutions for the problems. From these considerations, Barbara Fredrickson (2009) developed a model capable of explaining the social and cognitive effects of positive emotional experiences. According to this author, the experience of joy expands the domain of what a person wants to do at that moment, i.e., there is an expansion of the momentary repertoire of thought-actions. Observing a person who does something important and inspires admiration can also enhance positive emotions and change unfavorable pattern behaviors, as noted in studies by Jon Haidt (2002). Witnessing a heroic act, for example, leads the person to a state of elevation, which raises the manifestation of positive emotions.

Ken Sheldon and his colleagues attempted to explain human happiness from a model that integrates genetic aspects, circumstantial and demographic determinants and the process of intentional change. Although the genetic component is of greater weight, the authors emphasize intentional activity as a possibility of obtaining pleasure, meaning and good health (Lyubomirsky, Sheldon, \& Schkade, 2005), which emphasizes the processes of development as potentiators of the positive experience.

From the contributions of these different authors, aimed at different objectives, it is emphasized that the Positive Psychology proposal is a modification from the 
emphasis on repairing the worst aspects of life to building positive qualities or virtues (Seligman, 2000; Snyder \& Lopez, 2009). Since its inception, Positive Psychology has not been disseminated only in academia because it develops interventions and proposals that also involve non-academics, inviting them to benefit from its practices. An example of this growth is the International Association of Positive Psychology (Associação Internacional de Psicologia Positiva [AIPP]), which has over three thousand members distributed in 70 countries, bringing together not only researchers but also professionals of psychology and several other fields, who are interested in the study of well-being.

In 2005, Seligman and other researchers created the first academic program, Master of Applied Positive Psychology from the University of Pennsylvania (MAPP). This graduate program is directed to people who are already engaged in the work market and are able to afford the high tuition fees. Discussing themes such as coaching in different sectors, as well as the importance of developing the well-being in schools and universities, the program was considered revolutionary precisely because it aims to develop peoples' transforming potential.

\section{First Movement: Authentic Happiness}

There are many existing theories to explain happiness. There are those based in processes and activities, according to which happiness is produced when we engage in certain activities or work for a certain goal. Theories based on genetic and personality dispositions suggest that happiness may be a personality trait or characteristic more stable than those of genetic origin. Finally, there are the theories according which happiness lies in reducing stress through the satisfaction of goals and needs (Snyder \& Lopez, 2009). Thus, the postulations discussed in this study do not seek to solve this discussion or defend a single path but foster it from contact with various Positive Psychology studies, especially those by Seligman.

One of the first concepts studied by Seligman (1991) that contributed to the development of his notions on happiness was that of learned optimism. In that publication, the author recounts his journey through the studies about learned helplessness and highlights several benefits of the people considered optimistic as being more entrepreneurial and having better health. Optimists tend to assume that the problems experienced are temporary and due to external causes, seeking solutions that do not place them as guilty or as failures, and internalizing positive events. This ability to prove optimistic in the face of events not always favorable was considered one of the bases for Seligman's theoretical formulations, as we will see further on.

In 2004, the translation of the book Authentic Happiness was published in Brazil, a book that has been originally published by Seligman in the United States in 2002. Authentic happiness was the basis of Positive Psychology in the early days of its creation and development. This postulation recommends that happiness could be analyzed according to three different elements: positive emotion, engagement and meaning. Positive emotion consists of such sensations as pleasure, excitement, ecstasy and comfort among others. Engagement is related to a position of loss of self, i.e., complete loss of self during the performance of an activity considered pleasurable. Engagement refers to a loss in which the person has little awareness of their true sensations, only reports feeling much pleasure, being in a position of constant openness. According to Seligman (2004), all people can develop engagement in relation to an activity and should identify what those activities are and what features may favor the takeover of this position. The third element is meaning, and it relates to the search for purpose in life. A meaningful life consists of belonging and serving something you believe is greater than the self (Seligman, 2004). Humanity creates all the positive institutions that provide consistency for this search, such as religion, political parties, family, and the diverse social groups.

To summarize, authentic happiness assumes that Positive Psychology relates with happiness in three aspects: positive emotion, engagement and meaning. The measurement of happiness could be conducted from measuring tools that assess life satisfaction, the goal of Positive Psychology being to increase the level of life satisfaction. What strategies can contribute to increase satisfaction? What interventions are most effective in achieving this goal? What lifestyles promote this transformation? These questions were initially raised in an intervention plan based on authentic happiness. However, this position began to be questioned by Seligman from the results of his research throughout the first decade of this century.

Seligman is not the only author to propose models that lead people to the so-called happiness. Another important author in the field of Positive Psychology, Sonja Lyubomirsky (2008), presents a scientific method for people to achieve happiness, supported by exercises and strategies to promote positive emotions, such as expressing gratitude, cultivating optimism and positive social relationships, manage stress and adversities, develop focus on the present and commit to their goals. These characteristics should be exercised through a training program aiming at real and lasting happiness. Other studies were developed along the same lines, such as the work by Daniel Kahneman on hedonistic models of happiness.

Among the so-called deficiencies of this first Positive Psychology movement, Seligman (2011) noted that authentic happiness aims to redefine what happiness is in an arbitrary way. As to engagement and meaning, the notions are related to how the human being feel but are not part of what is conceived as happiness. Another criticism refers to the main measure of authentic happiness, which is the level of life satisfaction. According to studies recovered by Seligman (2011), mood could explain $70 \%$ of this index, while judgment of subjects' lives corresponds to $30 \%$. This perspective considers mood as the greatest predictor 
of happiness, which would lead to consider happiness as something transient and situational. An introverted person, for example, tends to be considered less happy than an extroverted one, which would not take into account the respondent perception or judgment about his emotions but only his moods. Also according to Seligman (2011), life satisfaction does not consider how much meaning there is or how much people are committed to their work and how much they engage with the people they love. As a possible measurement of mood, life satisfaction is extremely variable and is therefore a situational measurement. Based on these criticisms, Seligman and other researchers began to review the construct of authentic happiness, developing a second movement, known as well-being, which will be described next.

\section{Second Movement: Well-Being}

It is with the purpose of initiating a "new Positive Psychology" that Seligman (2011) starts his latest book. In that work, he proposes a change in the Positive Psychology goal: in 2004, it sought happiness. Currently, the term that Seligman uses is well-being. This change in nomenclature arose from several questions that emphasized happiness as a complex concept to be operationalized in terms of psychological construct. The term well-being, in contrast, has greater acceptance in scientific circles and summarizes, more appropriately, to what this referential proposes. Although the term well-being is more palatable in comparison with the concept of happiness, its discussion is not less complex, given the existence of different dimensions of well-being, such as psychological, emotional, subjective and social, among other subdivisions (Snyder \& Lopez, 2009). The adoption of these terms indicate different positions, comprising not only different factors promoters of well-being but also plural visions about the concept, as discussed in the studies by Ryff and Keyes (1995), which hinders consensus among the scholars in the field. The demarcation of these concepts, however, is not the target of Seligman's discussions, which is the reason why they will not be analyzed at this point.

When defining well-being, Seligman (2011) started from the classic definition of health proposed by the World Health Organization in 1946. To the absence of illness, Seligman adds the presence of positive emotions, leading to a situation of effective well-being. The author uses several cases and research findings on cardiovascular illnesses, cancer and infectious diseases to propose that exclusive focus on the disease does not always lead to a cure and that negative emotions, such as pessimism, hate, anger and depression, may be present in the etiopathogeny of many diseases.

Thus, focusing on disease prevention and health promotion, Seligman (2011) has listed several types of training that could and should be developed as a way to protect the population, leading to the adoption of a positive attitude and directly linked to well-being. According to his studies, optimists cultivate healthier attitudes, adopt healthier lifestyles and believe that their attitudes are important, unlike pessimists. Optimists also respond more adequately to medical prescriptions. People with high levels of satisfaction with life are more likely to watch what they eat, not smoke and exercise regularly, also having more regular sleep. Studies on positive health are still ongoing, raising many questions but already pointing to the beneficial effects of the adoption of predominantly positive attitudes regarding health conditions.

A new definition of Positive Psychology is proposed, defining Positive Psychology as the science that investigates well-being. According to this new proposition, well-being may be measured in relation to five factors: positive emotion, engagement, meaning, positive relationships and accomplishment. Positive emotion continues to be the main element in determining health, as well as authentic happiness, but because they are considered subjective measurements, happiness and life satisfaction become factors relevant to the well-being theory, although they cannot sustain well-being by themselves. Thus, the importance attributed to positive emotion is reduced. According to Seligman (2004), positive emotions can be related to past, present or future events. Those emotions related to the future include optimism, faith and hope. Emotions that pertain to the present encompass calm, plenitude, joy, ecstasy, excitement and pleasure. Linked to the past are feelings of satisfaction, contentment, accomplishment, pride and serenity. These three types of positive emotions related to time are not necessarily related to each other and can be measured individually using specific scales.

In terms of past experiences, an aspect in which Positive Psychology distances itself from psychodynamic traditions is when it states that the possible traumas or negative experiences of childhood, for example, do not necessarily lead to painful or distressing experiences in adulthood (Seligman, 2004). Thus, the events considered maladaptive in adulthood should be understood without necessarily seeking explanations in the past, but bringing up a series of present experiences focusing on the future, to achieve well-being and permanent accomplishment.

In this second movement, engagement remains as an element also evaluated subjectively, including such questions as "Have you had the feeling that time has stopped?" and "Were you completely absorbed by the task?". The third element, meaning, is not considered just a subjective state and is defined and measured independently from positive emotion or engagement. The element accomplishment (also known as achievement) highlights that the Positive Psychology goal is to describe, rather than prescribe, which people effectively do to achieve well-being. The fifth and last element, positive relationships, emphasizes the need for people to establish healthy relationships to achieve well-being. Interpersonal relationships are considered sources of support in anxiety moments and also as support for sharing moments of ecstasy and joy. Research recovered by Seligman (2011) noted that the loneliest people 
tend to report lower levels of well-being, while those who engage emotionally with others (in loving relationships, friendship or camaraderie) tend to develop more adaptive strategies to face situations considered difficult.

Well-being theory is plural in method as well as in substance: positive emotion is a subjective variable, defined by what you think and feel. Engagement, meaning, relationships and accomplishment have both subjective and objective components because you can believe you have engagement, meaning, good relations and high accomplishment and be wrong, even deluded. The upshot of this is that well-being cannot exist just in your head: it is a combination of feeling good as well as actually having meaning, good relationships, and accomplishment. The way we choose our course in life is to maximize all five of these elements. (Seligman, 2011, p. 36)

Thus, this second movement conceptualizes that the goal of Positive Psychology is to increase flourishing, a construct that encompasses the increase of positive emotion, engagement, meaning, positive relationships and accomplishment, involving an existence provided of a greater meaning. The flow state was notably investigated by Mihaly Csikszentmihalyi (1997) and involves the perceived challenges or opportunities for action that expand the existing personal skills. To increase the likelihood of producing flow, this author has developed, for instance, intervention programs that modify work environments. Other studies, as reported by Delle Fave and Massimini (1992), support the concept of flow as a state of optimal involvement in which the person does not realize the challenges of the action as an underutilization or burden of his actual skills but has clear and reachable goals, as well as immediate feedback on their progress (Snyder \& Lopez, 2009). As previously highlighted, the flow state can be achieved or enhanced from high levels of challenges and skills, which creates the possibility of understanding this concept as a promoter of attitudes of greater personal engagement in the resolution of problems, decreasing the weight given to external factors and prioritizing personal attitudes in the development of more suitable coping strategies and the capability of promoting significant changes.

This change in purpose, by itself, indicates an important transition in Positive Psychology, broadening the scope of this approach and enabling a more scientific examination of well-being. The highly-desired flourishing ceases to be a particular aspect and starts to be shared by communities such that the pursuit of well-being can be concrete, real and achievable. Obviously, further studies on what flourishing is, in fact, must be conducted, as well as on the effects of this concept on human development. In Brazil, the discussion is still in a premature state with only rare studies being conducted concerning the subject of flourishing; therefore, the information available is still fundamentally based on the findings of the international scientific community.

\section{Final Considerations}

To follow a decade of production in the field of Positive Psychology, mainly marked by the publication of two seminal works by Seligman, we observed several of his trajectories and positions assumed in relation to concepts concerning this approach. However, the choice of this author and works does not reflect the state-of-the-art scientific production on Positive Psychology nor does it aim to summarize the major advances in the field, which should be conducted from a closer dialogue with other contemporary authors, who have also contributed to the development of this field of knowledge. By comparing the two main movements highlighted by Seligman, one could understand what changes occurred and what are the possible repercussions of adopting these guidelines in Positive Psychology studies, while the second movement is still in its infancy.

As highlighted by Seligman (2011), authentic happiness attests that people make choices estimating how much happiness (satisfaction in life) they can achieve, choosing the paths that maximize the satisfaction. This maximization operation depends solely on the individual, i.e., satisfaction is an individual measurement, regardless of interactions and interpersonal relationships established. This operation is the first point where the well-being theory shows advances, as it incorporates the need for social relationships for development and the feeling of being happy and accomplished. In other words, social relationships have greater importance, overtaking the consideration of well-being as something solely individual. This point is closely related to the findings of many available studies, including those conducted by Lee, Seccombe and Shehan (1991) investigating married couples and by Diener and Seligman (2003) examining young people considered to be happy, to mention only two examples. Obviously, such consideration includes the possibility of designing intervention programs aiming at a collective well-being, supported by public policies.

As well-being is not related only to the individual, its promotion does not depend exclusively on the personal sphere, emphasizing the need for other institutions and decision-makers (government, political parties, public policies) to contribute to promoting well-being. This change in focus seems to herald the need for such institutions to be increasingly called upon to participate in the debate about well-being such that happiness is no longer a solely personal construct and linked to self-knowledge. These definitions are relevant guidelines to be developed in future studies.

Another significant change in the transition of these movements is that in authentic happiness, the standard of measurement is satisfaction with life, and its goal is to increase it. As to well-being, the standard of measurement is comprised of positive emotion, engagement, meaning, positive relationships and accomplishment, and the goal 
is to increase flourishing through potentialization of these elements. According to Seligman (2011), to flourish, an individual must have all characteristics considered essential (positive emotions, engagement, interest, meaning and purpose) and at least three of the six additional characteristics (self-esteem, optimism, resilience, vitality, self-determination and positive relationships). Such characteristics can be developed and constantly improved through training and specific interventions, which makes well-being a construct that can be achieved and constantly encouraged, as opposed to deterministic perspectives. The long-term challenge is to create strategies such that not only people but also institutions and countries can flourish, improving the quality of life and well-being of all to distribute the benefits of the joint effort more equally.

When drawing a parallel between these two movements, it is noted that the second movement not only proves to be more complex but also equates to a greater number of elements that must be analyzed in the understanding of what leads to well-being. The sense of accomplishment and establishment of positive relationships are added to the old tripod of authentic happiness, revealing the need for a judgment that overtakes the personal or individual dimension but considers the other(s) that is (are) in their surroundings or is (are) part of their life. This new theoretical framework clearly should be investigated in greater depth with the complex task of thinking about its possible long-term repercussions in the Positive Psychology studies. Although other theoretical postulations are in progress, guided by other researchers in the field, the scope of this new movement brought by Seligman is considered relevant and promising.

At the end of this study, it should be noted that we brought a first approximation between the two main theoretical Positive Psychology movements to date, which does not invalidate other incursions by these theories or even their revisions. Psychological science, as a body of knowledge in constant expansion and characterized by a marked theoretical-methodological dispersion, should allow such paradigm transitions to offer new perspectives on previously established approaches. It is in assuming the dialogue between distinct perspectives - which, of course, does not exclude the necessary theoretical clash - that knowledge production can advance, proposing renewed ways to learn, develop and assist human beings. Considering that well-being can be produced and encouraged raises the possibility of a less deterministic interpretation of the psychological science, placing responsibility on people, governments and institutions to constantly promote well-being through flourishing.

\section{References}

Albuquerque, A. S., \& Tróccoli, B. T. (2004). Desenvolvimento de uma escala de bem-estar subjetivo [Development of a scale of subjective well-being]. Psicologia: Teoria e Pesquisa, 20(2), 153-164.
Barros, R. M. A., Martín, J. I. G., \& Pinto, J. F. V. C. (2010). Investigação e prática em Psicologia Positiva [Research and practice in Positive Psychology]. Psicologia: Ciência e Profissão, 30(2), 318-327.

Buela-Casal, G., Olivas-Avila, J. A., Musi-Lechuga, B., \& Zych, I. (2011). The $\mathrm{h}$ index of the presidents of the American Psychological Association (APA) through journal articles included in the Web of Science database. International Journal of Clinical and Health Psychology, 11(1), 95-107.

Calvetti, P. U., Muller, M. C., \& Nunes, M. L. T. (2007). Psicologia da Saúde e Psicologia Positiva: Perspectivas e desafios [Health Psychology and Positive Psychology: Perspectives and challenges]. Psicologia: Ciência e Profissão, 27(4), 706-717.

Camargo, S. P. H., Abaid, J. L. W., \& Giacomoni, C. H. (2011). Do que eles precisam para serem felizes? A felicidade na visão de adolescentes [What do they need to be happy? The view of teenagers on happiness]. Revista Semestral da Associação Brasileira de Psicologia Escolar e Educacional, 15(2), 241-250.

Csikszentmihalyi, M. (1997). Finding flow. New York: Basic Books.

Dell'Aglio, D. D., Koller, S. H., \& Yunes, M. A. (2006). Resiliência e Psicologia Positiva: Interfaces do risco à proteção [Resilience and Positive Psychology: The interfaces of the risk protection]. São Paulo, SP: Casa do Psicólogo.

Delle Fave, A. (2006). Dimensions of well-being: Research and intervention. Milan, Italy: FrancoAngeli.

Delle Fave, A., \& Massimini, F. (1992). The experience sampling method and the measurement of clinical change: A case of anxiety disorder. In M. deVries (Ed.), The experience of psychopathology (pp. 280-289). Cambridge, England: Cambridge University Press.

Diener, E., \& Seligman, M. E. P. (2003). Very happy people. Psychological Science, 13, 81-84.

Ferraz, R. B., Tavares, H., \& Zilberman, M. L. (2007). Felicidade: Uma revisão [Happiness: A review]. Revista de Psiquiatria Clínica, 34(5), 234-242.

Fredrickson, B. L. (2009). Positividade: Descubra a força das emoções positivas, supere a negatividade e viva plenamente [Positivity: Discover the power of positive emotions, overcome negativity and live fully] (P. Libânio, Trad.). Rio de Janeiro, RJ: Rocco.

Giacomoni, C. H., \& Hutz, C. S. (2008). Escala multidimensional de satisfação de vida para crianças: Estudos de construção e validação [Multidimensional scale of satisfaction in life for children: Development and validation studies]. Estudos de Psicologia (Campinas), 25(1), 25-35.

Haidt, J. (2002). The positive emotion of elevation. In C. R. Snyder \& S. J. Lopez (Eds.), The handbook of Positive Psychology (p. 753). New York: Oxford University Press.

Hirsch, J. E. (2005). An index to quantify and individual's scientific research output. Proceedings of the National Academy of Sciences (PANAS), 102, 16569-16572.

Isen, A. M. (1987). Positive affect, cognitive processes, and social behavior. Advances in Experimental Social Psychology, 20, 203-253.

Larrauri, B. G. (2006). Programa para mejorar el sentido del humor: porque la vida con buen humor merece la pena [Program to improve mood: Because life in a good mood is worth-living]. Madrid, España: Pirámide.

Lee, G. R., Seccombe, K., \& Shehan, C. L. (1991). Marital status and personal happiness: An analysis of trend data. Journal of Marriage and the Family, 53, 839-844. 
Lemos, P. M., \& Cavalcante, F. S., Junior. (2009). Psicologia de orientação positiva: Uma proposta de intervenção no trabalho com grupos em saúde mental [Positive orientation psychology: A proposed intervention in mental health group work]. Ciência \& Saúde Coletiva, 14(1), 233-242.

Lyubomirsky, S. (2008). A ciência da felicidade: Como atingir a felicidade real e duradoura [The how of happiness: A scientific approach to getting the life you want] (M. Gama, Trad.). Rio de Janeiro, RJ: Elsevier.

Lyubomirsky, S., Sheldon, K. M., \& Schkade, D. (2005). Pursuing happiness: The architecture of sustainable change. Review of General Psychology, 9, 111-131.

Mesurado, B. (2009). Comparación de tres modelos teóricos explicativos del constructo experiencia óptima: o flow [Comparison of three theoretical models explicative of the optimal experience construct: The flow]. Interdisciplinaria, 26(1), 121-137.

Paludo, S. S., \& Koller, S. H. (2007). Psicologia Positiva: Uma nova abordagem para antigas questões [Positive Psychology: A new approach to old questions]. Paideia (Ribeirão Preto), 17(36), 9-20.

Park, N., \& Peterson, C. (2007). Methodological issues in Positive Psychology and the assessment of character strengths. In A. D. Ong \& M. H. M. Van Dulmen (Eds.), Oxford handbook of methods in Positive Psychology (pp. 292-305). New York: Oxford University Press.

Paschoal, T., \& Tamayo, A. (2008). Construção e validação da escala de bem-estar no trabalho [Construction and validation of the well-being scale at work]. Avaliação Psicológica, 7(1), 11-22.

Passareli, P. M., \& Silva, J. A. (2007). Psicologia Positiva e o estudo do bem-estar subjetivo [Positive Psychology and the study of subjective well-being]. Estudos de Psicologia (Campinas), 24(4), 513-517.

Pérez, C. L. (2009). Optimismo y salud positiva como predictores de la adaptación a la vida universitaria [Optimism and positive health as predictors of adaptation to academic life]. Acta Colombiana de Psicología, 12(1), 95-107.

Peterson, C., \& Seligman, M. E. P. (2003). Positive organizational studies: Thirteen lessons from Positive Psychology. In K. S. Cameron, J. E. Dutton, \& R. E. Quin (Eds.), Positive organizational scholarship: Foundations of a new discipline (pp. 14-27). San Francisco, CA: Berrett-Koehler.

Prati, L. E., \& Koller, S. H. (2011). Relacionamento conjugal e transição para a coparentalidade: Perspectiva da Psicologia Positiva [Marital relationship and transition to co-parenting: Positive Psychology Perspective]. Psicologia Clínica, 23(1), 103-118.

Rodrigues, A., \& Da Silva, J. A. (2010). O papel das características sociodemográficas na felicidade [The role of sociodemographic characteristics on happiness]. Psico-USF, 15(1), 113-123.

Ryff, C. D. (1989). Happiness is everything, or is it? Explorations on the meanings of psychological well-being. Journal of Personality and Social Psychology, 57(6), 1069-1081.

Ryff, C. D., \& Keyes, C. L. M. (1995). The structure of psychological well-being revisited. Journal of Personality and Social Psychology, 69(4), 719-727.

Scorsolini-Comin, F., \& Santos, M. A. (2009). A Psicologia Positiva no contexto brasileiro: História, presente e perspectivas futuras [Positive Psychology in the Brazilian context: History, present and future perspectives]. In S. N. Jesus, I. Leal, \& M. Rezende (Eds.), Experiências e intervenções em Psicologia da Saúde [Experiences and interventions in Health Psychology] (pp. 862-878). Faro, Portugal: Universidade do Algarve.
Scorsolini-Comin, F., \& Santos, M. A. (2010). Psicologia Positiva e os instrumentos de avaliação no contexto brasileiro [Positive Psychology and evaluation tools in the Brazilian context]. Psicologia: Reflexão e Crítica, 23(3), 440-448.

Scorsolini-Comin, F., \& Santos, M. A. (2011a). Casamento e satisfação conjugal: Um olhar da Psicologia Positiva [Marriage and marital satisfaction: A Positive Psychology view]. São Paulo, SP: Annablume.

Scorsolini-Comin, F., \& Santos, M. A. (2011b). Relações entre bem-estar subjetivo e satisfação conjugal na abordagem da Psicologia Positiva [Relationships between subjective well-being and marital satisfaction under the Positive Psychology approach]. Psicologia: Reflexão e Crítica, 24(4), 658-665.

Scorsolini-Comin, F., \& Santos, M. A. (2012). Correlations between subjective well-being, dyadic adjustment and marital satisfaction in Brazilian married people. The Spanish Journal of Psychology, 15(1), 166-176.

Seligman, M. E. P. (1991). Learned optimism. New York: Knopf. Seligman, M. E. P. (2000). Positive Psychology: An introduction. American Psychologist Association, 55(1), 5-14.

Seligman, M. E. P. (2002). Authentic happiness: Using the new Positive Psychology to realize your potential for lasting fulfillment. London: Nicholas Brealey.

Seligman, M. E. P. (2004). Felicidade autêntica: Usando a nova Psicologia Positiva para a realização permanente [Authentic happiness: Using the new Positive Psychology for permanent accomplishment] (N. Capelo, Trad.). Rio de Janeiro, RJ: Objetiva.

Seligman, M. E. P. (2011). Florescer: Uma nova compreensão sobre a natureza da felicidade e do bem-estar [Flourishing: A new understanding of the nature of happiness and well-being] (C. P. Lopes, Trad.). Rio de Janeiro, RJ: Objetiva.

Sheldon, K. M., \& King, L. (2001). Why Positive Psychology is necessary. American Psychologist, 56, 216-217.

Snyder, C. R., \& Lopez, S. J. (2009). Psicologia Positiva: Uma abordagem cientifica e prática das qualidades humanas [Positive Psychology: A scientific and practical exploration of human strengths] (R. C. Costa, Trad.). São Paulo, SP: Artmed.

Yunes, M. A. M. (2003). Psicologia Positiva e resiliência: O foco no indivíduo e na família [Positive Psychology and resilience: The focus on the individual and family] [Número especial]. Psicologia em Estudo, 8, 75-84. 